\title{
Performativity of Gandang Tasa in the Tabuik Naiak Pangkek and Hoyak Tabuik Rituals in Pariaman
}

\author{
Asril $^{1^{*} \quad \text { Andar Indra Sastra }}{ }^{1} \quad$ Adjuoktoza Rovylendes ${ }^{2}$ \\ 1. Karawitan Department, Faculty of Performing Arts \\ 2.Dance Department, Faculty of Performing Arts \\ Indonesian Institute of the Arts Padangpanjang, West Sumatra, Indonesia
}

This research was funded by the Directorate for Research and Community Service, Directorate General for Research and Development, Ministry of Research, Technology, and Higher Education, Republic of Indonesia.

\section{Abstract}

This article aims to reveal the performativity of gandang tasa in the tabuik naiak pangkek (tabuik for "raising the platform") and hoyak tabuik rites in the Tabuik ritual in Pariaman. Tabuik naiak pangkek is a ritual activity which combines two parts of the tabuik structure that have been made separately, namely pangkek ateh (the upper platform/section) and pangkek bawah (the lower platform/section). This ritual begins early morning and continues until later in the morning on the day of the Tabuik ritual. Throughout the ritual, the gandang tasa is played to make the atmosphere livelier. The hoyak tabuik ritual takes place in the afternoon and during this ritual, the tabuik is shaken, pounded, and carried on foot to the edge of Gandoriah Beach in Pariaman. Throughout the procession to the beach, the gandang tasa is played energetically and with full enthusiasm. The research results show that the performativity of gandang tasa in building an atmosphere of excitement plays a very important role, as shown by the gandang tasa players' behaviour, expressions, and total immersion in the music, as they become deeply involved in the ritual they are performing.

Keywords: Performativity, gandang tasa, tabuik naiak pangkek, and hoyak tabuik.

DOI: $10.7176 / \mathrm{ADS} / 76-02$

Publication date:September $30^{\text {th }} 2019$

\section{Introduction}

Tabuik is an annual ritual performed by the people of Pariaman City every year in the Muslim month of Muharam. The Tabuik ritual takes place from the beginning to around the middle of the month of Muharam. This ritual consists of a number of rites, including: maambiak tanah (collecting soil), maambiak/manabang batang pisang (collecting/cutting down a banana stem), maatam (circling a symbol that represents a grave), maradai (asking for donations), maarak jari-jari (parading the fingers), maarak sorban (parading the turban), tabuik naiak pangkek (raising the tabuik structure), hoyak tabuik (shaking the tabuik), and tabuik tabuang (submerging the tabuik in the sea). These last three rituals are all performed on the same day, beginning at dawn and continuing until just before dusk, starting with the tabuik naiak pangkek ritual, continuing with the hoyak tabuik ritual, and ending with the tabuik tabuang ritual. This day is the climax of the Tabuik ritual and is a spectacular, lively, joyful event witnessed by tens of thousands of people. The main focus of the ritual is the tabuik, a towerlike structure measuring 10-14 meters in height, known as tabuik gadang (large tabuik). The tabuik gadang consists of various attributes and symbols constructed by the Pariaman community including elements of the Minangkabau culture and influences of the Islamic culture that originate from the Tabut or Tabuik.

The climax of the ritual always involves two tabuik gadang, Tabuik Pasa and Tabuik Subarang, from the Pasa and Subarang communities. The Tabuik Pasa and Tabuik Subarang, along with all the other elements present to support the performance, including the tabuik gadang, tabuik lenong (small tabuik), ritual objects, ritual performers (anak tabuik/people performing the ritual in the field, ninik mamak/traditional leaders, community leaders, and young people), and the music of gandang tasa are the main elements that always participate in every Tabuik ritual or performance in Pariaman. If one of these elements is not present, the Tabuik ritual cannot be performed.

In general, the Tabuik ritual is supported by the percussion music of gandang tasa. However, more specifically, only two of the three rituals that form the climax of the Tabuik ritual - tabuik naiak pangkek and hoyak tabuik - always use gandang tasa to support the implementation of the ritual. Gandang tasa is a musical ensemble which performs rhythmic, dynamic, and energetic percussion music, traditionally performed only by men. This music is played from the beginning right up to the end of the tabuik naiak pangkek ritual and continues throughout the procession in which the tabuik gadang is paraded from the location of the tabuik naiak pangkek ritual to Gandoriah Beach. During this ritual, no other musical instruments or ensembles are played or used to support the atmosphere of the ritual. The presence of gandang tasa in these two rituals is seemingly very important for building an atmosphere of joy and excitement and arousing the enthusiasm of those participating in the tabuik naiak pangkek ritual so that they are able to complete their task. Similarly, in the hoyak tabuik ritual, gandang tasa is played while the tabuik gandang rests in one place and also throughout the procession towards 
the beach. The expressions and actions of the gandang tasa players adds to the excitement and fervour of the event. Another interesting aspect of this ritual is that the gandang tasa players readily allow the women present an opportunity to perform, either together with the men or by themselves as a group of all women. The embodiment or personification of the musicians through their attitudes in performing the music and their spontaneous actions, together with the effect of the music that they play, all appears to have a strong impact on the ritual. For example, the people participating in the ritual perform an attractive spectacle with the tabuik, shaking and pounding the tabuik, crashing into each other, and running around with it, despite its weight, which requires dozens of people just to lift it. This is an interesting phenomenon to observe from a performance perspective, in terms of the performativity of gandang tasa on the involvement of the music and the actions of the musicians, and its effect on the ritual.

A number of existing studies discuss the role of gandang tasa in the context of the Tabuik ritual and in other contexts, from various perspectives, including the perspective of performance. The writers who have carried out these studies include Asril, Andar Indra Sastra, and Adjuoktoza Rovylendes (2018) in an article entitled, "Performativity of Gandang Tasa in the Mauluik Ritual in Sicincin, Pariaman, West Sumatra." This article discusses the role of gandang tasa in building an atmosphere of excitement and frenzied fervour as the main part of the mauluik ritual procession in Sicincin, a nagari (village) in the Padang Pariaman Regency. The performativity of gandang tasa is manifested through the expressions, actions, and deep understanding or internalization of the gandang tasa players who are able to change the atmosphere of excitement and frenzied fervour into a trance.

The article "Peran Gandang Tasa dalam Membangun Spirit dan Suasana pada Pertunjukan Tabuik di Pariaman" (The Role of Gandang Tasa in Building the Spirit and Atmosphere of a Tabuik Performance in Pariaman) by Asril (2015) discusses the role of gandang tasa in various Tabuik rituals. Asril classifies the different kinds of atmosphere present in Tabuik rituals, from sadness, compassion, excitement, solemnity, and frenzy, to a dimension of violence that may lead to fighting between the Tabuik supporters. The important role of gandang tasa is in creating an atmosphere and emotion of anger and frenzied fervour with a dimension of violence, which triggers fighting and creates an atmosphere of excitement. Cameron Malik (2013) studies gandang tasa in the City of Pariaman, focusing on the piece entitled Sosoh in the Tabuik ritual. Malik observes how Sosoh is used to form an attitude of survival in the Tabuik ritual. The form of survival he is referring to is when Sosoh is performed during a rite which presents fighting between the supporters of Tabuik Pasa and Tabuik Subarang.

Based on these phenomena and the results of the library study, the phenomenon of gandang tasa in the performance of the tabuik naiak pangkek and hoyak tabuik rituals is interesting to discuss from the perspective of the gandang tasa players' involvement, both physically, and in terms of their gestures, expressions, and behaviour while performing, and especially the embodiment of the players when playing gandang tasa in the context of the tabuik naiak pangkek and hoyak tabuik rituals. This phenomenon is discussed from the perspective of performativity.

\section{Research Method}

The tabuik naiak pangkek and hoyak rituals are performances that involve gandang tasa music to support the enthusiasm of the performers and build an atmosphere of excitement. The data about the performance and performativity of gandang tasa was collected through field research, in particular by observing in careful detail the performance of gandang tasa in the context of the tabuik naiak pangkek and hoyak tabuik rituals. The reciprocal relationship between gandang tasa and these two rituals and the embodiment of the musicians when playing gandang tasa were the main focus of observation and data collection. The observation was carried out directly and recordings were made of every event so that all the events related to the performativity of gandang tasa in these rituals would not be lost. The audio-visual recordings were extremely important for storing data to facilitate the observation and analysis of the embodiment of the gandang tasa musicians, which includes their expressions, internalization, gestures, and behaviour. In order to explore the data in more depth, the writer also interviewed the gandang tasa players and ritual performers. The interviews were held in two ways - individually and in the form of a group panel discussion. The research approach to the performativity of gandang tasa focuses on the behaviour of the players and the embodiment of the players and the audience.

The findings of this research show that the performativity of gandang tasa in the tabuik naiak pangkek and hoyak tabuik rituals is able to build an atmosphere of excitement, as shown through the expressions, behaviour, and internalization of the gandang tasa players as a form of their embodiment of the music they are playing and an understanding and appreciation of the ritual they are performing. The effect of the performance of gandang tasa has a strong impact on the enthusiasm and passion of the ritual performers in their participation in the ritual process right up to the end. 


\section{Results and Discussion}

\subsection{Tabuik Naiak Pangkek Ritual}

Tabuik naiak pangkek is a ritual in which the two separate parts of the tabuik structure - the pangkek ateh and the pangkek bawah - are joined together. According to Asril: "Pangkek bawah is the lower section of the tabuik construction which consists of the legs of the tabuik and the burak, an element that is indicative of Shia culture, and symbolizes a vehicle for carrying the body of Husain. Pangkek ateh is the upper section of the tabuik construction and consists of several elements that can be visualized as elements of Minangkabau culture and also elements of Sunni culture, including bungo salapan (eight flowers), biliak-biliak (a chamber or room), gomaik (a pitcher or water jug), and puncak tabuik (the peak of the tabuik). All the elements of the pangkek ateh are new interpretations developed by the Pariaman community after the acceptance of Tabuik as a part of their culture at the beginning of the $20^{\text {th }}$ century" (Asril, 2016: 150). The tabuik naiak pangkek ritual is performed at the same time by both the Tabuik Pasa and Tabuik Subarang communities, beginning early in the morning, after the dawn prayers, and continuing until later in the morning, at separate locations. Tabuik Pasa performs the ritual in the Merdeka Field of Pariaman, while Tabuik Subarang performs the same ritual in Simpang Tabuik. An example of the tabuik naiak pangkek ritual can be seen in photo 1 below.

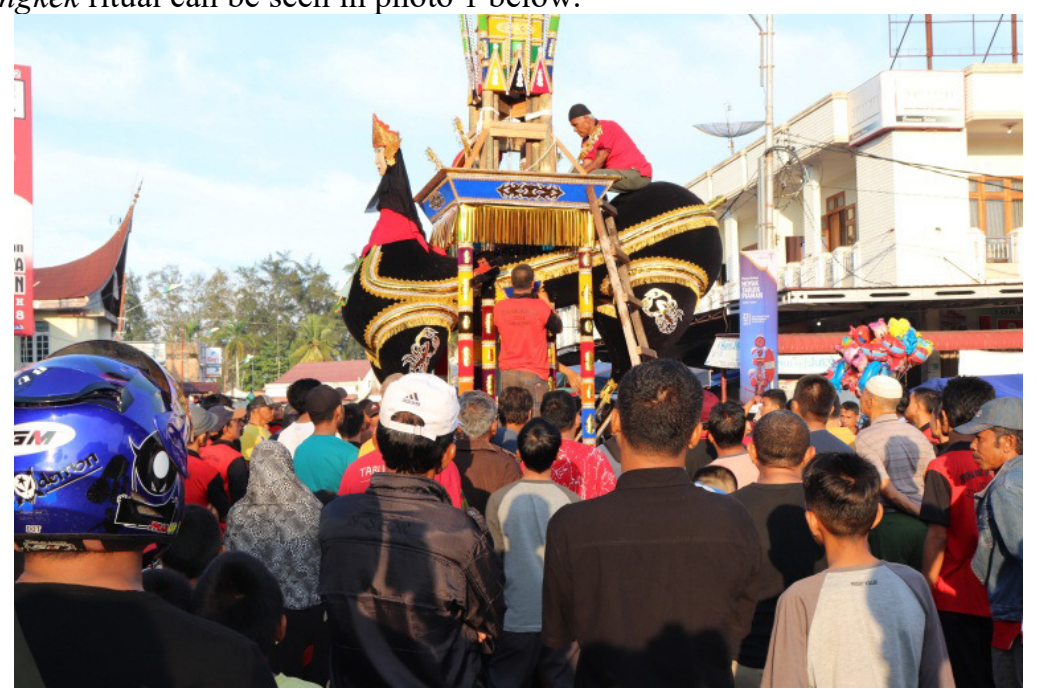

Figure 1: Process of the tabuik naiak pangkek ritual performed by the anak tabuik from the Tabuik Subarang community (Photo: Asril, September 2018).

The process of the tabuik naiak pangkek is performed in two different ways. Tabuik Pasa usually continues the old method, with everyone helping to raise the pangkek ateh together, with the use of supporting poles, and then attaching it to the pangkek bawah that has been lifted into an upright position with a height of around 6-7 meters. The process of combining the two parts of the structure takes quite a long time and the atmosphere is tense, because the pangkek ateh structure is quite tall (around 6-7 meters) and heavy, so great care is needed to keep it balanced and prevent it from toppling over. The process of combining the two parts of the construction is an exciting spectacle for those watching. Meanwhile, for Tabuik Subarang, the process of assembling the two pangkek is much simpler and more practical, since it uses a tipper truck (Asril, 2016: 192). The pangkek ateh is tilted at an angle and placed in the back of the truck, while the pangkek bawah remains on the ground below, and the two pangkek are then fastened together. This takes much less time and involves less risk. Tabuik Subarang has used this method for the past two decades. However, in the tabuik naiak pangkek ritual that took place in September 2018, the method used by Tabuik Pasa had changed to follow the same method used by Tabuik Subarang. The tabuik naiak pangkek ritual involves participants from various elements of the community, including tuo tabuik (elders in the tradition of Tabuik), ninik mamak (traditional leaders), anak tabuik (the ritual performers, consisting of young people, including the gandang tasa players), and the tabuik makers.

While the ritual is taking place, gandang tasa ensembles play in both locations to create a festive atmosphere. The gandang tasa performance may last up to two hours or for the entire duration of the tabuik naiak pangkek ritual. The musicians take turns to play the gandang tasa. The pieces performed are Oyak Tabuik and Sosoh. These two pieces are special pieces that are only performed on the occasion of the tabuik naiak pangkek ritual. The characteristics of these two pieces are their fast tempo, high energy, and lively character which helps raise the spirits and enthusiasm of the ritual performers who are involved in the tabuik naiak pangkek ritual. In the piece Sosoh, in particular, the mood of joy and excitement is also demonstrated by the gandang tasa players, who make spontaneous movements as a reaction to the music that they are playing. Similarly, the audience watching the ritual, especially the women, dance along with the gandang tasa players. The Figures 2 and 3 below show examples of gandang tasa being played during the process of the tabuik naiak 
pangkek ritual.

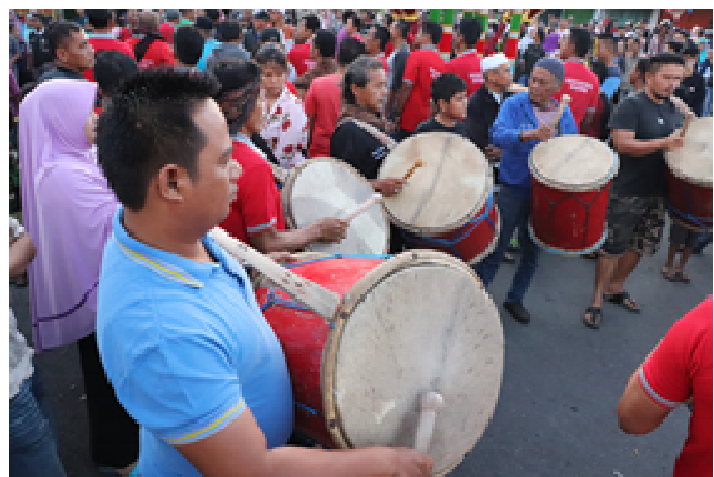

Figure 2 .

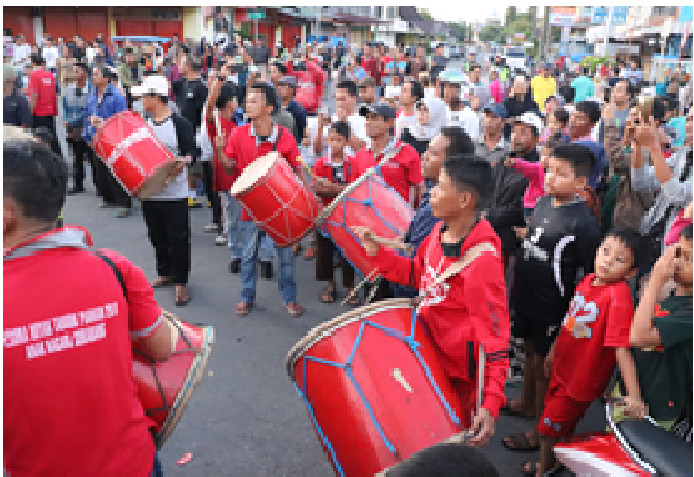

Figure 3.

Figures 2 and 3 show the gandang tasa being played by the Tabuik Subarang group during the process of the tabuik naiak pangkek ritual at Simpang Tabuik, Pariaman, the location of the ritual for the Tabuik Subarang community. Members of the audience can also be seen interacting with the musicians (Photo: Asril, September 2018).

Although tabuik naiak pangkek is a ritual that is traditionally performed only by the members of each tabuik community, in the case of the gandang tasa groups, the musicians offer the opportunity for women in the audience to play the drums. It is an interesting spectacle to see women playing the drums because in Pariaman, women do generally not play the traditional music of gandang tasa. While some of the women are playing the drums, other women dance as a spontaneous reaction and outpouring of excitement. They join together with the other gandang tasa players who are all men and boys. The women's enthusiasm is apparent as they play the drums while the process of assembling the two pangkek takes place. They draw the attention of the audience, even though their drumming skills may not be very good. An example of women playing the drums can be seen in Figure 4 below.

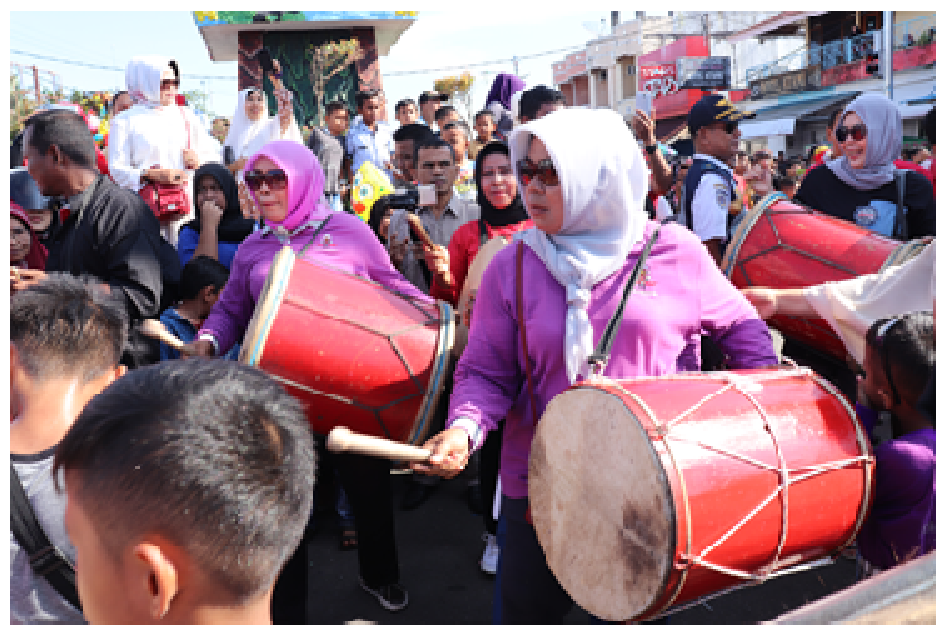

Figure 4. Women participating in playing gandang tasa to support the atmosphere of excitement during the tabuik naiak pangkek ritual (Photo: Asril, September 2018).

After the tabuik naiak pangkek ritual has ended, and the tabuik gadang has been constructed, along with all the attributes that make the tabuik complete, the two tabuik stand upright in a strategic position in each of their own locations. Tabuik Pasa stands at the crossroads of Pariaman Market, while Tabuik Subarang stands at Simpang Tabuik. The position of the two tabuik indicates the areas to which they belong, which are separated by a bridge that goes across the Batang Air Pampan River (Asril, 2016: 192-193).

\subsection{Hoyak Tabuik Ritual}

Hoyak tabuik is the climax of the entire sequence of the Tabuik ritual from the beginning (maambaiak tanah) to the final stage of tabuik tabuang. The performance is colossal and festive, and involves various other performing arts such as dance and music. The term hoyak tabuik comprises the words hoyak and tabuik. Hoyak comes from the word oyak, which means the activity of pounding, shaking, moving around (KBBI, 2014: 992). Hoyak tabuik, therefore, is the activity of pounding, shaking, rocking, and swinging around the tabuik gadang. Specifically, Asril writes: "Hoyak tabuik is an attractive performance that is performed using the tabuik gadang as the object of attraction, which is rocked, shaken, raised and lowered, swung around, pounded, crashed into, and carried 
around at great speed" (Asril, 2016: 151).

Over the last few years, the implementation of hoyak tabuik has undergone a number of fundamental changes. For example, from 2016 to the present day (2018), the venue for the climax of the hoyak tabuik ceremony has been Gandoriah Beach, in Pariaman, whereas previously this ritual was always performed in the Merdeka Field in Pariaman. Now that the ritual is held at Gandoriah Beach, the ritual process is preceded by the procession of the two tabuik gadang to Gandoriah Beach from their place of origin, namely Simpang Tabuik for the Tabuik Subarang community and Pariaman Market for the Tabuik Pasa community. This procession is performed in succession by the two groups, beginning with the Tabuik Pasa community and followed by the Tabuik Subarang community. During the procession of the two tabuik gadang, the gandang tasa groups play as they walk along the road. The audience also joins them as they process to Gandoriah Beach, and the roads are filled with people watching and the ritual performers themselves.

This procession tends to be more like a parade, and rarely presents the attraction of shaking and pounding the tabuik gadang, except when the groups stop at certain places along the way, such as in front of Pariaman Market and in front of the Pariaman Railway Station. When the procession of the tabuik gadang stops in these two places, it offers an opportunity for a special performance of gandang tasa. The audience's attention is directed towards the gandang tasa and the players demonstrate various styles, behaviour, expressions, and gestures, which are full of excitement and enthusiasm, despite the scorching heat of the midday sun. The piece Sosoh dominates the performance. Meanwhile, women watching the performance begin dancing in time with the music of the gandang tasa. The drum beat and rhythms of this piece have strong accents, creating a tempo suitable for dancing. Sometimes men also join in with the dancing. They interact with the gandang tasa players, ignoring the hot weather. One interesting aspect of the performance is when the two tabuik gadang stop not too far away from each other, and both groups show their joy and excitement through the music of the gandang tasa, while the dancers also move from one tabuik to the other. The loud beating of the drums in the piece Sosoh in both places draws the dancers close. The performance of gandang tasa continues until the procession ends at Gandoriah Beach.

\subsection{Performativity of Gandang Tasa}

The study of the performativity of gandang tasa focuses on the performance of gandang tasa in the context of the two rituals, tabuik naiak pangkek and hoyak tabuik. The performativity is observed through the actions or performance of the gandang tasa players while they perform the pieces Oyak Tabuik and Sosoh, with particular focus on their expressions, behaviour, gestures, and actions that emerge spontaneously as an outpouring of their elation. The predicate of gandang tasa changes to become not only an object but also a verb, meaning to present a performance through the musicians. Performativity, according to Austin, is a real action, presenting a performance of what is desired, not only through words or speech (Fischer-Lichte, 2008: 24; Schechner, 2013: 110). This action of a performance is what is meant by performative. This means that the performance of gandang tasa in the context of the tabuik naiak pangkek and hoyak tabuik rituals is not limited only to words or actions, but is a true performance, given in all reality and with all sincerity. Hence, the analysis of performativity focuses on performance.

The performance of gandang tasa in the tabuik naiak pangkek ritual is manifested through the expressive performance of the gandang players. They create an atmosphere of excitement and enthusiasm early in the day to trigger the passion of the ritual performers in the tabuik naiak pangkek ritual. Although they only play the piece Hoyak Tabuik and more specifically the piece Sosoh, the bias of the musical expression and players' expressions themselves influence the atmosphere and encourage the audience to respond to the rhythms of the music by dancing. Some of the women even take turns playing the drums, despite the fact it is not a suitable instrument for them to play. The drum in a gandang tasa ensemble is a large percussion instrument with a masculine character. Meanwhile, the ritual participants appear high spirited in performing all their tasks related to the tabuik naiak pangkek ritual until it is assembled to become a tabuik gadang that is ready to be shaken and carried around. This shows that the performativity of gandang tasa in the tabuik naiak pangkek ritual is not only for filling in time or as an illustration. As explained by Ajo Syafruddin Auang, an elder of Tabuik Subarang, who also plays the drum on certain occasions, "Without gandang tasa, this ritual lacks passion and excitement, and can even be likened to a death ritual" (Ajo Syafruddin Auang, interview 23 September 2018). It is clearly not easy to create and maintain an atmosphere of excitement while playing gandang tasa for more than two hours. However, the gandang tasa players are able to create this excitement through their deep understanding and internalization of the Tabuik in general and in particular the tabuik naiak pangkek ritual, which is the pride and identity of the Pariaman community. This sense of pride in being the 'owner' of a tradition is an important asset which helps develop the performance of the musicians to become a joyful experience.

Meanwhile, in the hoyak tabuik ritual, the performativity of gandang tasa also presents an atmosphere of joy and enthusiasm. This can be observed in the expressions and behaviour of the players that arises through their movements and in their bright smiles, despite playing under the heat of the midday sun. The struggle 
between exhaustion, heat, and enthusiasm merges together. They appear to be playing not in pretence but with full enthusiasm and as an honest service. The procession covers a distance of approximately only 500 meters but takes around 2 hours; an exhausting 2 hours in which the players' energy is drained by playing the percussion music of gandang tasa under the sun's burning rays.

The music performed by the gandang tasa ensemble and expressed by the players is not only enjoyed by the gandang tasa players themselves but also by the dozens of people carrying the tabuik gadang. The accentuated rhythms of the gandang tasa music with its strong beat seem to encourage them and give them the energy to carry the tabuik gadang, which weighs close to half a tonne. The performativity of gandang tasa that appears on the surface is an expression of delight, complete with its various actions and bias, but behind this there is a stimulus of energy for all the people participating in the ritual, giving them the enthusiasm needed to perform the ritual. The power of the gandang tasa performance that becomes its performativity is in the performance that takes place in the procession. Figure 5 below shows a performance of gandang tasa at the time of a hoyak tabuik ritual, with the joyful expressions of the musicians.

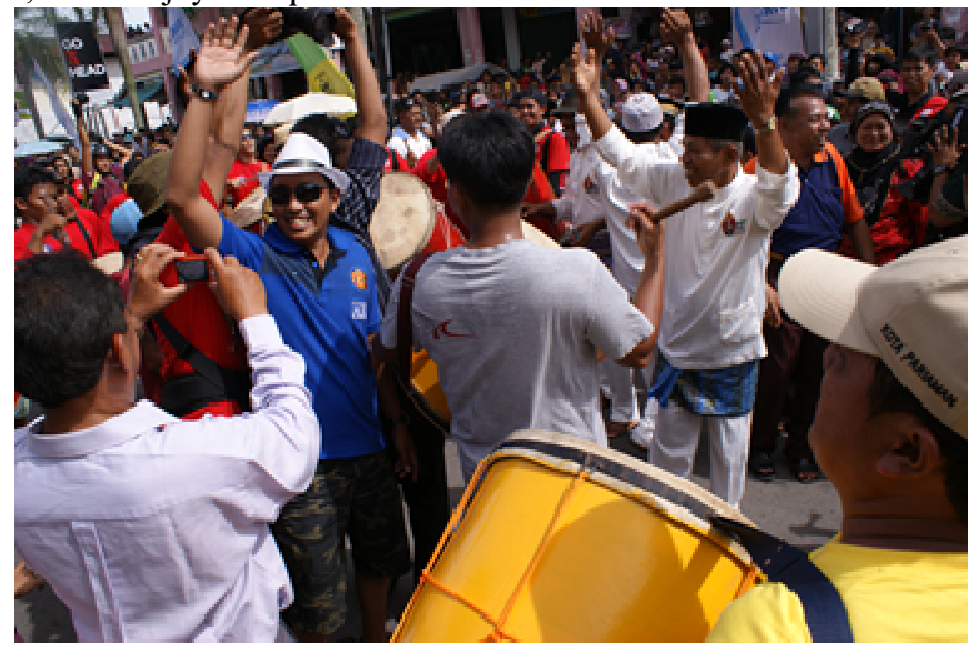

Figure 5: Performance of gandang tasa at a hoyak tabuik ritual, showing the audience and other ritual performers interacting and expressing their excitement as they laugh and raise their arms in response to the music played by the gandang tasa ensemble (Photo: Asril).

The situation used to be different when the hoyak tabuik ritual was still held in the Merdeka Field in Pariaman, and the 200 meter stretch along the main road from Simpang Tabuik to Pariaman Market was the area for staging the hoyak tabuik ritual. This was an occasion for the attraction of hoyak tabuik to be performed in a dramatic manner. As Asril explains, in his research study a number of years prior to 2016:

"The tabuik, with a height of 10-14 meters and a weight of approximately half a tonne, was performed attractively by the anak tabuik. Each group of anak tabuik, consisting of 20-30 people, performed attractions with the tabuik [gadang]: it was rocked, shaken, raised and lowered, swung around, pounded, crashed into, and carried around at great speed. The interesting attractions of the hoyak ritual included lifting and crashing into the tabuik and running with it in the direction of the other tabuik, to put pressure on and challenge the 'opponents'. The uproar of their voices mixed with the beating rhythms of the drums playing the piece Oyak Tabuik in an expression of joy. The people carrying the tabuik that was being 'put under pressure' did not accept this treatment from their 'opponents'. In the same way they pushed their opponents as hard as they could to move back to their own place. The performance grew louder because it was supported by the gandang tasa which incited the passion of the tabuik bearers. The sweltering heat and sweat drenching their bodies did not dampen their passion in performing the attraction. In turn, the groups continued to pressure each other. They appeared to be enjoying what they were doing. The attractions in hoyak tabuik sometimes also sparked tension between the supporters of the tabuik groups, as an element of conflict and drama in the performance, but there was never fighting or scuffling. This was a theatrical performance of Tabuik presented by dozens of performers" (Asril, 2016: 194).

The change in location for the climax of the hoyak tabuik ritual has also affected the performativity of gandang tasa in the hoyak tabuik ritual. In 2016, the effect caused by the performance of gandang tasa in the hoyak tabuik ritual on the other ritual performers, and specifically the people carrying the tabuik gadang, was very powerful. The role of gandang tasa in the various rites of Tabuik has been charted by Asril (2015: 73), in particular in the context of the hoyak tabuik ritual, in which gandang tasa functions as a stimulus to raise a "patriotic" spirit as well as including a dimension of violence. The aspect of embodiment of the gandang tasa 
players in their response to the pieces they play and the ritual in which they participate form a closely bound entity. Simatupang defines embodiment as a process in which thoughts are manifested in the form of bodily actions. The expressions that arise during a performance can be understood as an activity of manifestation and realization in various forms, arising from the experiences and thoughts and deep internalization of what they are doing (Simatupang, 2013: 76-77). This shows that the performativity of gandang tasa is determined by the embodiment of the players, from their experiences, thoughts, internalization, and understanding of the two rituals. Without this, it is not possible that they would be able to express the passion of the ritual and their own passion, manifested through their behaviour in the performance.

\section{Conclusion}

The performativity of gandang tasa in the performance of the tabuik naiak pangkek and hoyak tabuik rituals is shown through the embodiment of the gandang tasa players in their playing of the music, their understanding and internalization of the ritual, and their thoughts, which create an atmosphere of excitement in these two rituals. The forms of embodiment are manifested by the musicians by playing with an emotion of joy, as demonstrated through their gestures, expressions, internalization, and actions, performing with a spirit full of elation. This condition has a strong influence on the ritual performers, including the anak tabuik who perform the tabuik naiak pangkek and the people carrying the tabuik gadang, with hearts full of passion and enthusiasm. Gandang tasa is a strong stimulus in the tabuik naiak pangkek and hoyak tabuik rituals, creating a spirit of passion and an atmosphere of excitement. Without the performance of gandang tasa in these two rituals, the performance of the rituals would be imperfect.

\section{Bibliography}

Asril. (2016). "Tabuik: Pertunjukan Budaya Hibrid Masyarakat Kota Pariaman, Sumatra Barat.” Dissertation, Doctoral Program Art Creation and Studies. Yogyakarta: ISI Yogyakarta.

Asril. (2015). "Peran Gandang Tasa dalam Membangun Spirit dan Suasana pada Pertunjukan Tabuik di Pariaman”. In Jurnal Humaniora, Volume 27, Number 1, p. 67-80.

Asril. Sastra, Andar Indra. dan Rovylendes, Adjuoktoza. (2018). "Performativity of Gandang Tasa in the Mauluik Ritual in Sicincin, Pariaman, West Sumatra.” In Art and Design Studies Journal. Vol. 67, p. 15-23.

Departemen Pendidikan Nasional. (2014). Kamus Besar Bahasa Indonesia. Jakarta: Gramedia.

Fischer-Lichte, Erika. (2008). The Transformative Power of Performance: A new aesthetics. London and New York: Routledge.

Malik, Cameron. (2013). "Musik Sosoh Untuk Membentuk Sikap Kebertahanan Dalam Upacara Tabuik di Pariaman Sumatra Barat". Thesis, Ethnomusicology, ISI Surakarta.

Schechner, Richard. (2002, 2013). Performance Studies: an Introduction. London: Routledge.

Simatupang, Lono. (2013). Pergelaran: Sebuah Mozaik Penelitian Seni Budaya. Yogyakarta: Jalasutra. 